\title{
Angiotensin-converting enzyme inhibitory peptides from Lactobacillus delbrueckii QS306 fermented milk
}

\author{
Nan Wu, Weihan Xu, Kangling Liu, Yanan Xia, and Shuangquan* \\ Department of College of Food Science and Engineering, Inner Mongolia Agricultural University, Hohhot, 010018, People's Republic of China
}

\begin{abstract}
Angiotensin-converting enzyme inhibitory peptides were isolated and identified from milk fermented using Lactobacillus delbrueckii QS306. The peptide with the highest angiotensin-converting enzyme inhibitory activity (C5) was purified using ultrafiltration with 10 and $3 \mathrm{kDa}$ molecular mass cut-off membranes, Sephadex G-15 (Sigma-Aldrich, St. Louis, MO) gel filtration chromatography, reversed-phase HPLC, and Orbitrap Elite (Thermo Fisher Scientific Inc., Waltham, MA) liquid chromatography-tandem mass spectrometry. We obtained peptide LPYPY by microbial fermentation, which was derived from $\kappa$-casein $\mathrm{f}$ (AA 77-81). We synthesized LPYPY using an Fmoc solid-phase synthesis method and explored the secondary structure of the pentapeptide. The half maximal inhibitory concentration for the angiotensin-converting enzyme inhibitory activity of LPYPY was $12.87 \mu \mathrm{g} / \mathrm{mL}$. The results provide additional information for ongoing research and the development of functional foods having antihypertensive effects.
\end{abstract}

Key words: angiotensin-converting enzyme inhibitory peptide, Lactobacillus delbrueckii QS306, fermented milk, purification, identification

\section{INTRODUCTION}

In recent years, hypertension has become a serious noncontagious disease and is considered a major worldwide cause of mortality and morbidity (Zafari et al., 2017). Hypertension can cause cardiovascular disease, coronary heart disease, heart failure, and kidney disease (Tikhomirova et al., 2017). In 2016, the World Health Organization (WHO) reported that cardiovascular disease caused the death of more than 17.7 million people every year and was responsible for about

Received October 25, 2018.

Accepted March 7, 2019.

*Corresponding author: shuangquan@imau.edu.cn
$31 \%$ of all deaths worldwide (WHO, 2016); hypertension was responsible for at least $50 \%$ of these cases (Kumar and Yin, 2018). Recently, many studies have aimed to develop methods to prevent hypertension and to clarify the relationships between lifestyle behavior and hypertension prevention (Nolan et al., 2018), including the risks associated with obesity, malnutrition, and smoking (Antman et al., 2014).

Angiotensin-converting enzyme (ACE, EC 33.4.15.1, CD143) is an important factor in blood pressure regulation and vascular remodeling (Tikhomirova et al., 2017). The ACE is a membrane-bound, multifunctional enzyme containing a glycoprotein moiety and is located on the surface of various cells, including epithelial, endothelial, neuroepithelial, and immune system cells (Ehlers and Riordan, 1989; Bernstein et al., 2012). The ACE has extracellular signal transduction and antigen capabilities. Although ACE also exerts antifibrosis and antiinflammatory effects (Shori and Baba, 2014), its main importance is its association with decreased hypertension. Therefore, controlling ACE activity is an important factor to treat hypertension. Many antihypertensive drugs are available on the market, including captopril, lisinopril, alacepril, and enazepril (Radó et al., 1985; Nagata et al., 1997). Clinical studies have shown that synthetic ACE inhibitors (ACEI) have negative effects on humans (Kumar et al., 2000); therefore, natural ACE inhibitory peptides from milk (Seppo et al., 2003), meat (Jang and Lee, 2005), eggs (Liu et al., 2010), grains (Jia et al., 2010), fruit, and vegetables have been isolated and investigated with the aim of replacing conventional antihypertensive drugs.

Fermented dairy products provide daily energy and nutrition requirements in many countries (Daliri et al., 2018). Common fermentation starters include Lactobacillus helveticus, Lactobacillus delbrueckii ssp. bulgaricus, and Streptococcus salivarius ssp. thermophilus. Fermented dairy products contain functional peptides that exert antibacterial, antioxidation, and antihypertensive effects (Cho et al., 2007, Fang et al., 2007). For example, milk fermented by L. helveticus was reported to reduce blood pressure in humans, reducing systolic and diastolic blood pressures by 6.7 and $3.6 \mathrm{mmHg}$, re- 
spectively (Seppo et al., 2003). Lactobacillus delbrueckii ssp. bulgaricus and Streptococcus thermophilus are components of LB81 yogurt, and long-term consumption of this product has beneficial effects on maintaining systemic homeostasis (Usui et al., 2018). Nakamura et al. (1995a,b) used L. helveticus and Saccharomyces cerevisiae as starter cultures to ferment the drink Calpis, which has angiotensin-converting enzyme inhibitor (ACEI) activity. The peptides valine-proline-proline and isoleucine-proline-proline have substantial bloodpressure-lowering effects and have become the most widely used milk-derived ACEI peptides (GonzalezGonzalez et al., 2013; Solieri et al., 2015). Lactobacillus delbrueckii is a probiotic that has been reported to regulate heat fatigue, to control the intestinal gut microflora, and to produce bioaccessible peptides ( $\mathrm{Li}$ et al., 2017; Archer et al., 2018). Makino et al. (2018) reported that yogurt fermented with $L$. delbrueckii ssp. bulgaricus could stimulate the immune system and had anti-fatigue effects. Moreno-Montoro et al. (2018) reported that goat milk fermented using L. delbrueckii ssp. bulgaricus and S. salivarius ssp. thermophilus contained potentially beneficial peptides, such as the ACEI peptide, dipeptidyl peptidase IV inhibitor (DPP-IV), and antibacterial peptides.

Although the activity of protein-derived bioactive peptides is enhanced by enzymatic hydrolysis or the use of probiotic species, including $L$. delbrueckii, there is a distinction with regard to research on the influence of $L$. delbrueckii as a single strain to ferment skim milk to produce ACE-inhibitory activity. Furthermore, the peptide was predicted by ExPASy (https://www.expasy .org/) and digested by gastrointestinal enzymes. Moreover, the peptide was synthesized by Fmoc-protected AA synthesis methods and the secondary structure was studied. Therefore, the aim of the present study was to examine the ACEI peptide from milk fermented by L. delbrueckii QS306, which could be applied in the development and use of dairy products in the future.

\section{MATERIALS AND METHODS}

\section{Materials}

Lactobacillus delbrueckii QS306 was initially isolated from a traditional dairy product and was provided by the National Food Research and Development Team of the College of Food Science and Engineering, Inner Mongolia Agricultural University.

We obtained hippuryl-L-histidyl-L-leucine (HHL), ACE (EC 3.4.15.1, from rabbit lung), and azocasein from Sigma-Aldrich (St. Louis, MO). All other chemicals were obtained commercially and were of analytical or chromatographic grade.

\section{Cultivation of Strains and Preparation of Fermented Milk}

We cultured L. delbrueckii QS306 for 3 generations in de Man, Rogosa, and Sharpe (MRS; Guangdong Huankai Microbial Sci. \& Tech. Co., Ltd., Guangzhou, China) broth at $37^{\circ} \mathrm{C}$ for $24 \mathrm{~h}$, centrifuged the cells $\left(3,000 \times g\right.$ for $15 \mathrm{~min}$ at $\left.4^{\circ} \mathrm{C}\right)$, and then suspended them in sterilized saline water (approximately $10^{8} \mathrm{cfu} /$ $\mathrm{mL})$. We then added a $3 \%$ ( $\mathrm{vol} / \mathrm{vol}$ ) culture to sterile reconstituted skim milk (11\%; wt/vol) and incubated it at $37^{\circ} \mathrm{C}$ for $48 \mathrm{~h}$. All the experiments were performed in triplicate.

\section{Peptide Concentration}

We measured free acid radicals using ortho-phthalaldehyde, as described by Minervini et al. (2003) and Tsai et al. (2006), to calculate the peptide concentration. We measured the absorbance of the peptide sample using the ortho-phthalaldehyde method, and then evaluated the concentration of the polypeptide in the fermented milk using a tyrosine standard curve.

\section{ACE-Inhibitory Activity}

We determined the ACEI activity using the method described by Cushman and Cheung (1971) with some modifications (Table 1). We mixed the treated sample and centrifuged it at $3,000 \times g$ at $4^{\circ} \mathrm{C}$ for $10 \mathrm{~min}$ and then transferred the supernatant $(0.8 \mathrm{~mL})$ to a $1-\mathrm{mL}$ centrifuge tube. We used ethyl acetate to remove the hippuric acid formed, after which the sample was heat evaporated at $70^{\circ} \mathrm{C}$ for $120 \mathrm{~min}$, redissolved in deionized water, and analyzed spectrophotometrically at $228 \mathrm{~nm}$. The activity of each sample was evaluated in triplicate using the following equation:

$$
\text { ACEI rate }(\%)=(\mathrm{Aa}-\mathrm{Ab}) /(\mathrm{Aa}-\mathrm{Ac}) \times 100,
$$

where Aa is the absorbance without sample (buffer only), $\mathrm{Ab}$ is the absorbance in the presence of both $\mathrm{ACE}$ and sample, and Ac is the absorbance of the blank. The percentage of ACEI at a given peptide nitrogen concentration or the peptide concentration needed to inhibit $50 \%$ of the original ACE activity $\left(\mathbf{I C}_{50}\right)$ were used to represent the inhibitory activity (Hernandez-Ledesma et al., 2010).

\section{Purification of ACEl Peptides from Fermented Milk}

Preparation of the Original Peptide Samples. We adjusted the $\mathrm{pH}$ of the samples $(100 \mathrm{~mL})$ to 4.6 using $1 \mathrm{M} \mathrm{HCl}$ and then centrifuged them at 3,000 $\times g$ at 
$4^{\circ} \mathrm{C}$ for $20 \mathrm{~min}$. We readjusted the $\mathrm{pH}$ the supernatants to $\mathrm{pH} 7.0$ using $1 \mathrm{M} \mathrm{NaOH}$ and centrifuged the samples again at $3,000 \times g$ at $4^{\circ} \mathrm{C}$ for $10 \mathrm{~min}$. We adjusted the $\mathrm{pH}$ of the resulting final supernatants to 8.3 using $1 \mathrm{M}$ $\mathrm{NaOH}$, centrifuged them at $3,000 \times g$ at $4^{\circ} \mathrm{C}$ for $5 \mathrm{~min}$, and stored them at $-20^{\circ} \mathrm{C}$.

Ultrafiltration. We pipetted the final supernatants $(10 \mathrm{~mL})$ into UF centrifuge tubes [molecular weight (MW) cut-off of $10 \mathrm{kDa}$; Amicon Ultra-15 mL, Millipore, Billerica, MA]. We collected 2 fractions (MW $<10$ and $\mathrm{MW}>10 \mathrm{kDa}$ ) and then re-centrifuged the fraction with the highest ACEI activity in UF centrifuge tubes with a MW cut-off of $3 \mathrm{kDa}$ (Amicon Ultra-15 $\mathrm{mL}$, Millipore). We collected 2 fractions (MW $<3$ and $\mathrm{MW}>3 \mathrm{kDa}$ ). The fraction with the highest ACEI activity was freeze-dried and stored at $4^{\circ} \mathrm{C}$.

Isolation of ACEI Peptides. We dissolved the freeze-dried samples in deionized water and separated them using a Sephadex G-15 (Sigma-Aldrich, St. Louis, $\mathrm{MO})$ gel filtration column $(1.5 \mathrm{~cm} \times 50 \mathrm{~cm})$. We injected $1.5 \mathrm{~mL}$ of the sample $(300 \mathrm{mg} / \mathrm{mL})$ into the column. Deionized water eluted the samples at a rate of $0.3 \mathrm{~mL} /$ min. We measured the optical density of the eluates at $228 \mathrm{~nm}$ and gathered them at 2-min intervals. We further purified the fractions with the highest ACEI activity using reversed-phase (RP) HPLC.

\section{RP-HPLC}

We carried out RP-HPLC using a Thermo U3000 HPLC system configured with a C18 column (Thermo C18 $4.6 \times 250 \mathrm{~mm}, 5 \mu \mathrm{m}$, Thermo Fisher Scientific Inc., Waltham, MA). We injected the samples $(100 \mu \mathrm{L})$ and eluted them at a rate of $1 \mathrm{~mL} / \mathrm{min}$ using a linear gradient as follows: 0 to $10 \mathrm{~min}, 0.05 \% \mathrm{~A} ; 10$ to $12 \mathrm{~min}$, 0.05 to $10 \% \mathrm{~A} ; 12$ to $37 \mathrm{~min}, 10$ to $35 \% \mathrm{~A} ; 37$ to $38 \mathrm{~min}$, 35 to $100 \% \mathrm{~A}$; and 38 to $39 \mathrm{~min}$, and 100 to $0.05 \% \mathrm{~A}$. The elution system was composed of solution A: $0.05 \%$ (vol/vol) trifluoroacetic acid in 100\% (vol/vol) acetoni- trile and solution B: $0.05 \%$ (vol/vol) trifluoroacetic acid in water. We detected the effluent fractions (optical density at $228 \mathrm{~nm}$ ), lyophilized them, and assayed their ACEI activity and free acid radicals.

\section{Identification of Peptides Using Orbitrap Elite LC-MS/MS}

We determined the molecular weights and AA sequences of the purified peptides using an Orbitrap Elite LC-MS/MS (Thermo Fisher Scientific Inc.) equipped with a C18 column $(1.8 \mu \mathrm{m}, 0.15 \times 100 \mathrm{~mm}$, Thermo Fisher Scientific Inc.). The elution system was composed of solution A: $0.1 \%(\mathrm{vol} / \mathrm{vol})$ formic acid in water and solution B: $100 \%$ (vol/vol) acetonitrile. We spotted $1 \mu \mathrm{L}$ of solution onto a stainless steel target. We operated the Orbitrap Elite LC-MS/MS in the positive refractor mode and the mass range was scanned from 350 to 1,000 Da. The activity time was $10 \mathrm{~ms}$ and the normalized collision energy was 35.0. We further analyzed the major peak obtained after the first MS using a second MS. We analyzed the AA sequence using a DeNovo Explorer (AB SCIEX, Framingham, MA) and confirmed the results using Peaks 7.5 software (Bioinformatics Solutions Inc., Waterloo, ON, Canada).

\section{Identification and Screening of the ACEI Peptides}

We used the UniProt database (https://www.uniprot .org) to identify the ACEI activity of the fermented milk peptides, which were subsequently compared with reported ACE inhibition peptides. We used the ExPASy-PeptideCutter tool to predict the cleavage site of the peptide sequence using 28 enzymes and chemicals at http://www.expasy.org/tools.

\section{Fmoc Solid Phase Synthesis of Peptides}

Ontores Biotechnologies Corporation (Zhejiang, China) synthesized the identified potential ACE inhibi-

Table 1. Determination of angiotensin-converting enzyme (ACE) inhibitory activity ${ }^{1}$

\begin{tabular}{|c|c|c|c|}
\hline \multirow[b]{2}{*}{ Reagent } & \multicolumn{3}{|c|}{ Sample ( $\mu \mathrm{L}$ unless indicated) } \\
\hline & $\mathrm{Aa}$ & $\mathrm{Ab}$ & $\mathrm{Ac}$ \\
\hline $\mathrm{HCl}(1 \mathrm{~mol} / \mathrm{L})$ & 0 & 0 & 200 \\
\hline $\mathrm{ACE}$ & 40 & 40 & 40 \\
\hline Whey & 0 & 40 & 0 \\
\hline $\mathrm{H}_{2} \mathrm{O}$ & 40 & 0 & 40 \\
\hline Reaction conditions & $37^{\circ} \mathrm{C} 5 \mathrm{~min}$ & $37^{\circ} \mathrm{C} 5 \min$ & $37^{\circ} \mathrm{C} 5 \mathrm{~min}$ \\
\hline HHL & 80 & 80 & 80 \\
\hline Reaction conditions & $37^{\circ} \mathrm{C}$ for $40 \mathrm{~min}$ & $37^{\circ} \mathrm{C}$ for $40 \mathrm{~min}$ & $37^{\circ} \mathrm{C}$ for $40 \mathrm{~min}$ \\
\hline $\mathrm{HCl}$ & 200 & 200 & 0 \\
\hline Ethyl acetate $(\mathrm{mL})$ & 1 & 1 & 1 \\
\hline
\end{tabular}

${ }^{1} \mathrm{HCl}=$ hydrochloric acid; HHL = hippuryl-L-histidyl-L-leucine; $\mathrm{Aa}=$ the absorbance without sample (buffer only); $\mathrm{Ab}=$ the absorbance in the presence of both $\mathrm{ACE}$ and sample; $\mathrm{Ac}=$ the absorbance of the blank. 
Table 2. Angiotensin-converting enzyme inhibitor (ACEI) activity of peptide segments separated by molecular membrane $\mathrm{UF}^{1}$

\begin{tabular}{lccccc}
\hline Sample & Whey & MW $>10 \mathrm{kDa}$ & $\mathrm{MW}<10 \mathrm{kDa}$ & $3 \mathrm{kDa}<\mathrm{MW}<10 \mathrm{kDa}$ & $\mathrm{MW}<3 \mathrm{kDa}$ \\
\hline ACEI $(\%)$ & $75.58 \pm 1.69^{\mathrm{b}}$ & $70.05 \pm 1.91^{\mathrm{a}}$ & $86.80 \pm 1.29^{\mathrm{d}}$ & $79.79 \pm 0.96^{\mathrm{c}}$ & $89.89 \pm 0.89^{\mathrm{e}}$ \\
$\mathrm{IC}_{50}(\mu \mathrm{g} / \mathrm{mL})$ & $0.570 \pm 0.003$ & $0.550 \pm 0.005$ & $0.426 \pm 0.006$ & $0.428 \pm 0.004$ & $0.324 \pm 0.003$ \\
\hline
\end{tabular}

${ }^{a-e}$ Within a row, means with different letters are significantly different $(P<0.05)$.

${ }^{1}$ Analyses were performed in triplicate. Values are means $\pm \mathrm{SD} . \mathrm{MW}=$ molecular weight; $\mathrm{IC}_{50}=$ half maximal inhibitory concentration.

tion peptide using a solid-phase synthesis method. The purity of the peptide was determined using HPLC at $98.29 \%$. Electrospray ionization MS was used to determine the molecular mass.

\section{Stability of the Peptide During In Vitro Digestion by Gastrointestinal Enzymes}

We dissolved pepsin solutions (1\%; wt/wt) in 0.1 $\mathrm{m} M \mathrm{KCl}$ and $\mathrm{HCl}$ buffers adjusted to $\mathrm{pH} 2.0$ and $\mathrm{pH}$ 1.3 , respectively; we adjusted the $\mathrm{pH}$ of a chymotrypsin (1\%; wt/wt) solution in a $0.1 \mathrm{mM} \mathrm{KCl-NaOH}$ buffer to $\mathrm{pH} 7.2$, and adjusted the $\mathrm{pH}$ of a $1 \%$ (wt/wt) trypsin solution in a $0.1 \mathrm{mM} \mathrm{KCl-NaOH}$ buffer to $\mathrm{pH} 7.2$. We dissolved the synthesized peptide at $1.0 \mathrm{mg} / \mathrm{mL}$ in the pepsin, trypsin, or chymotrypsin solution, and reacted them at $37^{\circ} \mathrm{C}$ for $3 \mathrm{~h}$. In a separate experiment, we treated the purified peptide with trypsin and pepsin, chymotrypsin at $37^{\circ} \mathrm{C}$ for $3 \mathrm{~h}$ in each step, and another step from the method of Chen et al. (2012).

\section{Circular Dichroism Spectroscopy}

We next performed circular dichroism spectroscopy to study the secondary structure of the identified potential ACEI peptide using a J-715 spectrophotometer. We determined the measurement range of the peptide between 190 and $250 \mathrm{~nm}$ with a scanning speed of 50 $\mathrm{nm} / \mathrm{min}$. The Jwstda 32 software (Jasco, Tokyo, Japan) was used to express the results.

\section{Analysis the Physicochemical Characteristics of ACE Inhibitory Peptide}

We used the ExPASy tool to analyze the isoelectric point, molecular weight, instability index, and grand average of hydropathicity. We then used the PepDraw Tool to assay the net charge and hydrophobicity of the peptide (http://www.tulane.edu/ biochem/WW/ PepDraw/).

\section{RESULTS AND DISCUSSION}

\section{ACEI Activity of Fermented Milk Supernatant and UF}

The $\mathrm{pH}$ of the Lactobacillus delbrueckii QS306 fermented milk was 4.3 after $48 \mathrm{~h}$ of fermentation. The
ACEI activity of whey had an $\mathrm{IC}_{50}$ value of $0.570 \pm$ $0.003 \mathrm{mg} / \mathrm{mL}$.

In this study, we used UF to separate the fermented milk supernatants into 2 fractions $(\mathrm{MW}>10 \mathrm{kDa}$, MW $<10 \mathrm{kDa})$. The results indicated that the $\mathrm{MW}<10$ $\mathrm{kDa}$ fraction had the highest ACEI activity. Peptides below 3,000 Da express effective ACE inhibitory effects; therefore, we centrifuged the MW $<10 \mathrm{kDa}$ sample using a MW cut-off of $3 \mathrm{kDa}$. As shown in Table 2, the peptide concentration of ACEI was $1.3 \mathrm{mg} / \mathrm{mL}$, and the fraction with a MW $<3 \mathrm{kDa}$ showed the highest ACEI activity, which was then subjected to Sephadex gel chromatography for further purification.

\section{Isolation of ACEI Peptides with G-15 Sephadex}

As shown in Figure 1, we observed 4 major absorbance peaks at $228 \mathrm{~nm}$. Table 3 shows the ACEI activity of the peaks at a protein concentration of $0.6 \mathrm{mg} /$ $\mathrm{mL}$. Peak $\mathrm{C}$ contained the highest ACEI activity, with an $\mathrm{IC}_{50}$ value of $0.051 \mathrm{mg} / \mathrm{mL}$. We further purified and analyzed fraction C using an Orbitrap Elite LC-MS/ MS.

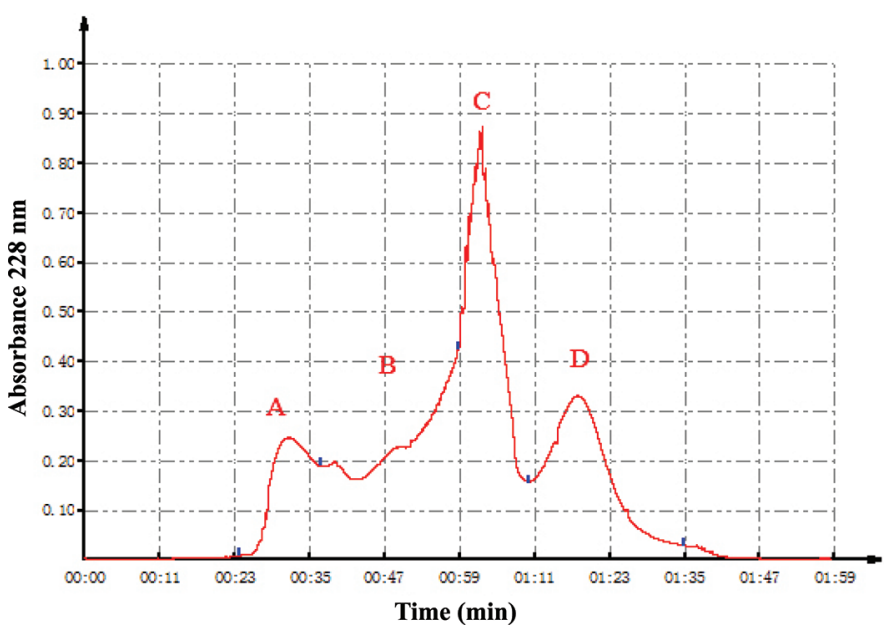

Figure 1. Sephadex G-15 (Sigma-Aldrich, St. Louis, MO) chromatogram. A, B, C, and D are the 4 major absorbance peaks at 228 $\mathrm{nm}$. 
Table 3. Angiotensin-converting enzyme inhibitor (ACEI) activity of each component using a Sephadex G-15 (Sigma-Aldrich, St. Louis, MO) chromatogram $^{1}$

\begin{tabular}{lcccc}
\hline Fraction & A & B & C & D \\
\hline ACEI $(\%)$ & $12.68 \pm 1.58^{\mathrm{a}}$ & $27.39 \pm 1.83^{\mathrm{b}}$ & $74.87 \pm 0.67^{\mathrm{d}}$ & $55.47 \pm 1.15^{\mathrm{c}}$ \\
\hline
\end{tabular}

${ }^{\mathrm{a}-\mathrm{d}}$ Within a row, means with different letters are significantly different $(P<0.05)$.

${ }^{1}$ Analyses were performed in triplicate. Values are means $\pm \mathrm{SD}$.

\section{Purification of ACEl Peptides with RP-HPLC}

We used RP-HPLC to purify fraction $\mathrm{C}$ and the resultant 5 peaks are shown in Figure 2. Peaks C3, C4, and $\mathrm{C} 5$ contained ACEI activity; the inhibition rates at a protein concentration of $40 \mu \mathrm{g} / \mathrm{mL}$ were $65.94 \pm$ $2.77,82.79, \pm 2.09$, and $93.86 \pm 1.04 \%$, respectively. Figure 3 shows the RP-HPLC chromatogram for peak C5. Peak C5 contained the highest ACEI activity, with an $\mathrm{IC}_{50}$ of $12.87 \mu \mathrm{g} / \mathrm{mL}$. We collected and lyophilized this fraction for further identification. Figure 4 shows the $\mathrm{IC}_{50}$ values of the samples under different separating conditions. The RP-HPLC-purified sample showed an ACEI activity that was approximately 44 times that of the whey sample.

\section{AA Sequences of the Purified Peptide}

To analyze AA sequences, Edman degradation requires peptides with sufficient purity and quantity. Moreover, the $\mathrm{N}$ terminus, protected by the polypeptide, cannot be sequenced. In addition, the overall sequencing speed is relatively slow. Therefore, MS has emerged as the first choice for peptide identification. The PEAKS software (Bioinformatics Solutions Inc., Waterloo, ON, Canada) and a de novo sequencing method were used to analyze the secondary mass spectrum for fraction C5 (Figure 5). Finally, we identified a pentapeptide sequence, LPYPY, with a score of 98 , which was detected in C5 13 times more frequently than the sum of the other sequences. Therefore, we inferred that the main AA sequence of C5 was LPYPY (Leu-Pro-Tyr-Pro-Tyr), having a molecular weight of 651.326 Da. The UniProt analysis indicated that the source of this sequence included $\kappa$-casein, glutathione peroxidase, and superoxide dismutase. We concluded that the sequence was derived from $\kappa$-casein $\mathrm{f}$ (AA 77-81) because the polypeptide was isolated from fermented skim milk.

Gomez-Ruiz et al. (2007) isolated peptides from casein fractions of raw ovine milk using enzymatic hydrolysis and reported that one of the identified peptides that exhibited ACEI activity was LPYPY. Zhang et al. (2015) synthesized LPYPY and built a back propagation neural network model to predict the $\mathrm{IC}_{50}$ of $\mathrm{ACE}$ of pentapeptides. The result showed that

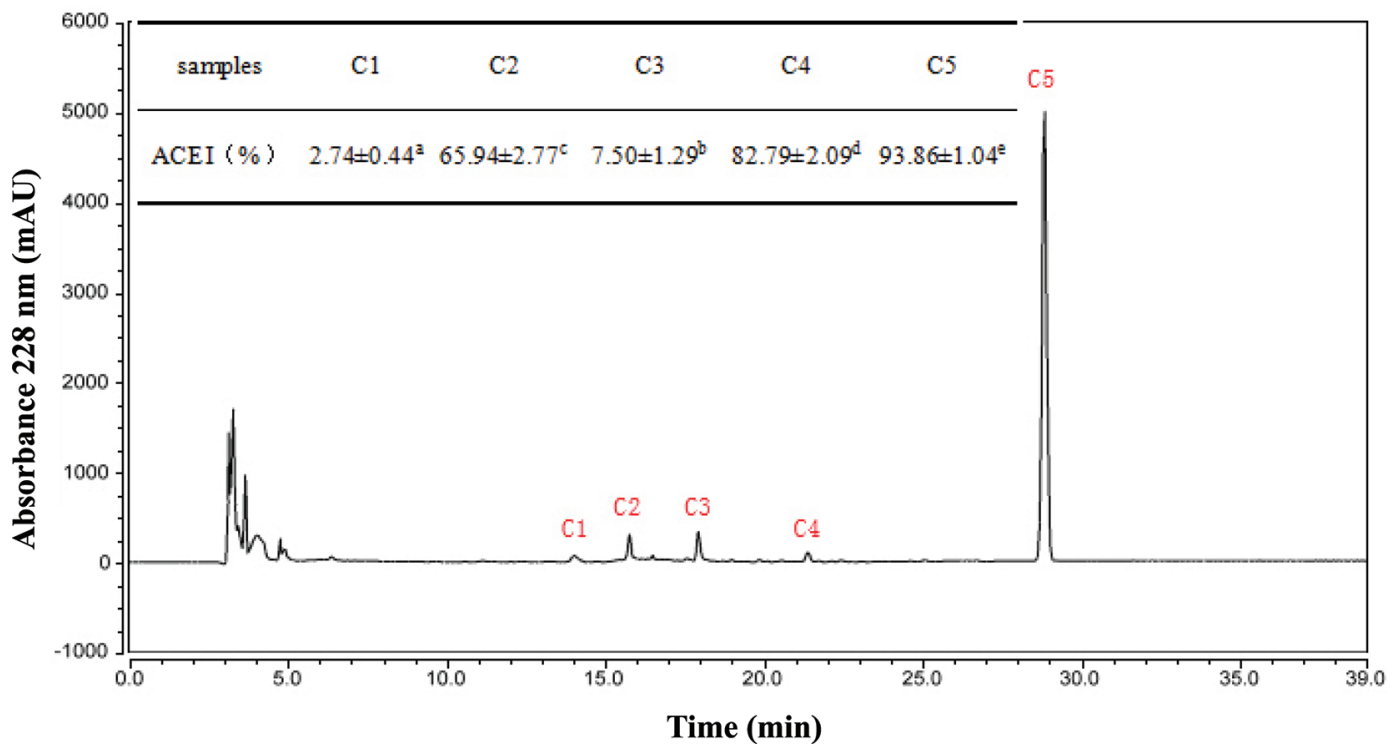

Figure 2. Reversed-phase high-performance liquid chromatography (RP-HPLC) chromatogram of fraction C and angiotensin-converting enzyme inhibitor (ACEI) activity of the chromatogram peaks. Means with different letters $(\mathrm{a}-\mathrm{e})$ are significantly different $(P<0.05)$. 


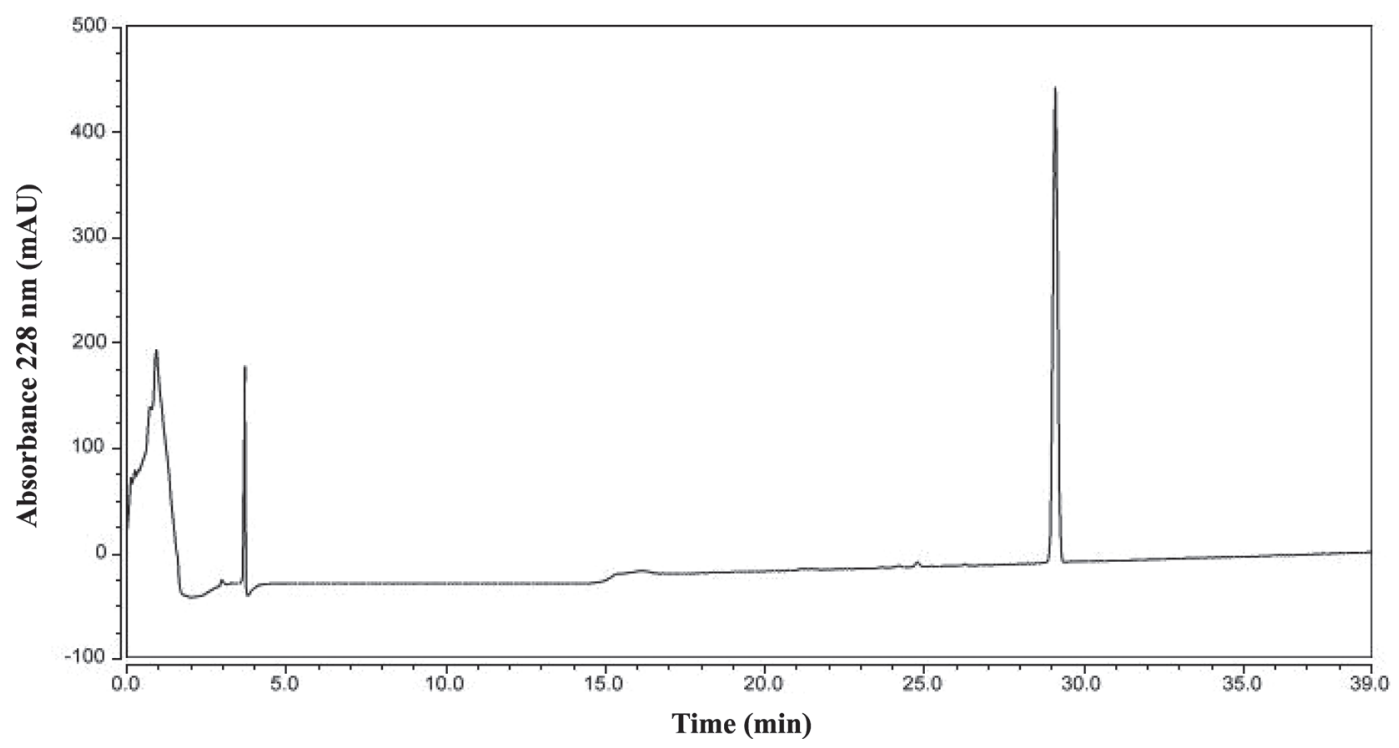

Figure 3. Reversed-phase high-performance liquid chromatography (RP-HPLC) chromatogram of fraction C5.

a greater the degree of $\mathrm{ACE}$ inhibition was obtained as the distance between the $\mathrm{Zn}^{2+}$ and the carbonyl oxygen of the peptide became shorter. This study suggested that an enzyme kinetics investigation, as well as docking and molecular dynamics simulation analysis, should be applied in the research and development of ACE inhibitory peptides. Nongonierma and Fitzgerald (2014) digested protein-derived peptides from milk using a gastrointestinal enzyme in silico and reported a LPYPY peptide. The authors also discussed the relationship between the bioavailability of functional foods exhibiting DPP-IV inhibition and the potential blood sugar-guiding properties in humans, and the scavenging activity toward 2,2-diphenyl-1-picrylhydrazyl radicals. Studies have shown that LPYPY is mostly produced via enzymatic hydrolysis; therefore, LPYPY was obtained by microbial fermentation. The PepDraw Tool indicated that the hydrophobicity of the active peptide was $+5.51 \mathrm{kcal} / \mathrm{mol}$ and that the hydrophobic AA at the $\mathrm{N}$ terminus could significantly increase its ACEI activity (Wu et al., 2006). The ExPASy Tool indicated that the aliphatic index was 78 and that aliphatic AA such as Tyr, His, and Lys at the $\mathrm{C}$ terminus could significantly improve its ACEI activity (Ngo et al., 2014). In the present study, the identified LPYPY sequence contained Tyr and Leu AA residues, which might contribute to its ACEI activity. The molecular modeling technique, coupled with the biological assays for ACE inhibition, indicated the active ingredients at the catalytic cleft of ACE with chemical groups or bonds coordinating $\mathrm{Zn}$ (II) to complete the stable geometry (Jimsheena and Lalitha, 2010; Guerrero et al., 2012). We will use the molecular modeling technique to explore the relationship between LPYPY and ACE active pocket.

\section{Stability and ACEI Property of the Peptide}

The ProtParam module of the ExPASy Tool indicated that the instability index (II) was 71.20 , which classifies the peptide as unstable. The PeptideCutter library indicated that 3 types of enzymes (pepsin, trypsin, and K-protease) would affect the LPYPY peptide structure and that it would be unstable during digestion. Pepsin hydrolyzes mainly carboxy terminal peptide bonds containing hydrophobic AA residues such as Phe, Trp, and Tyr, and the identified peptide has the sequence Ley-Pro-Tyr-Pro-Tyr. Based on pepsin digestion ( $\mathrm{pH}$

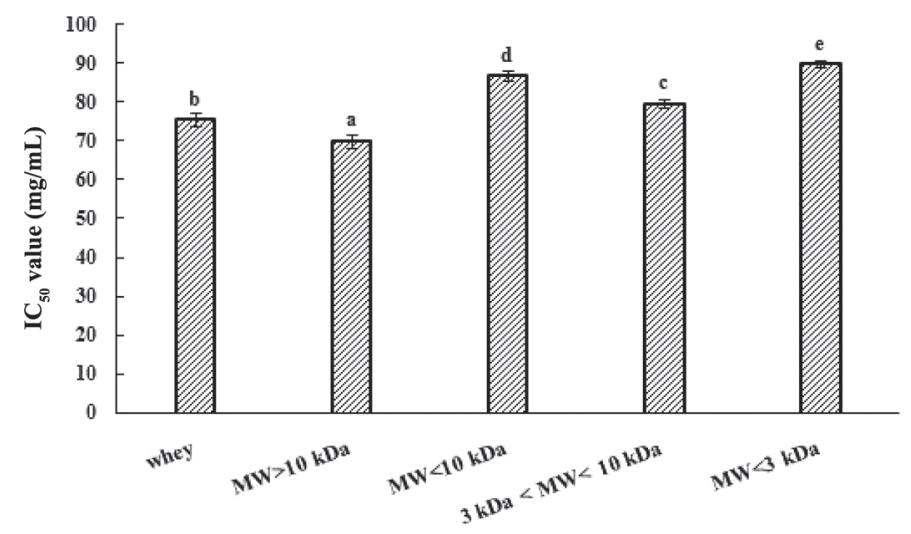

Figure 4 . The half maximal inhibitory concentration $\left(\mathrm{IC}_{50}\right)$ values of samples under different separation conditions. Error bars represent SE. $\mathrm{MW}=$ molecular weight. Means with different letters $(\mathrm{a}-\mathrm{e})$ are significantly different $(P<0.05)$. 


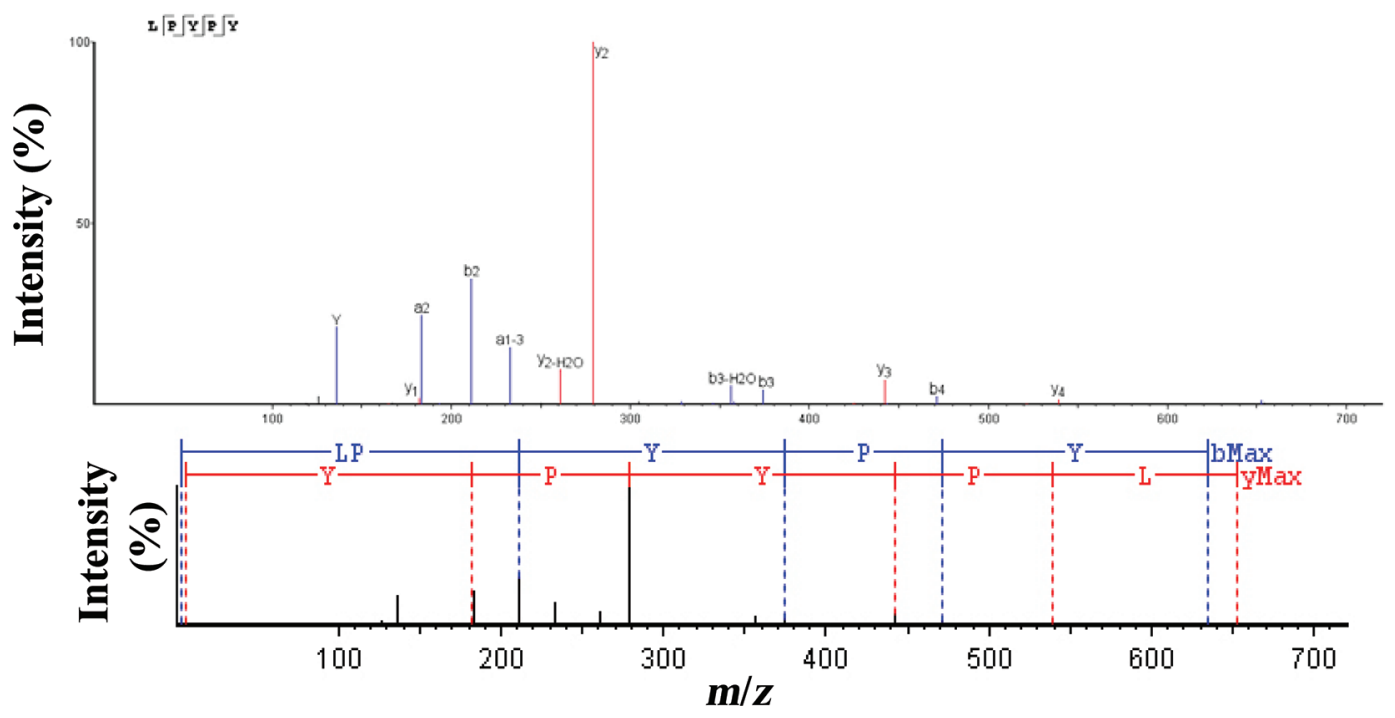

Figure 5. Orbitrap Elite (Thermo Fisher Scientific Inc., Waltham, MA) liquid chromatography-tandem mass spectrometry (LC-MS/MS) spectrum of fraction C5.

$>1.3$ and $\mathrm{pH}>2$ ), the LPYPY sequence may become PYPY $(\mathrm{pH}>1.3)$ and PY $(\mathrm{pH}>2)$. Trypsin was not predicted to change the LPYPY sequence. Previous studies showed that a Pro AA residue at the $\mathrm{C}$ terminus of peptides could significantly increase their ACEI activity (Norris et al., 2015).

Three gastrointestinal proteases (pepsin, trypsin, and chymotrypsin) were used to digest LPYPY and the ACEI activity increased significantly $(P<0.05)$

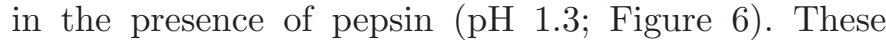
results indicated that the peptide was unstable and that a high hydrogen ion concentration may increase the ACEI activity.

\section{Secondary Structure Characterization of the Peptide}

Circular dichroism spectroscopy was used to analyze the secondary structure of the peptide using JWSSE32 software (Figure 7). The secondary structure consisted of beta-pleated sheet $74.6(\%)$, turn $12.5 \%$, random coil $7.2 \%$, and $\alpha$-helix $5.7 \%$. The results indicated that the $\beta$-sheet was the main contributor to the ACEI activity. Tu et al. (2018) reported similar results.

\section{CONCLUSIONS}

We isolated and purified a pentapeptide sequence, LPYPY, from fermented milk samples using L. delbrueckii QS306. The peptide exhibited ACE inhibitory effects, with an $\mathrm{IC}_{50}$ of $12.87 \mu \mathrm{g} / \mathrm{mL}$. Although the peptide was unstable, its ACE inhibitory activity was relatively high after $\mathrm{pH} 1.3$ pepsin digestion. The peptide sequence was derived from $\mathrm{k}-\mathrm{CN} \mathrm{f}$ (77-81), with a
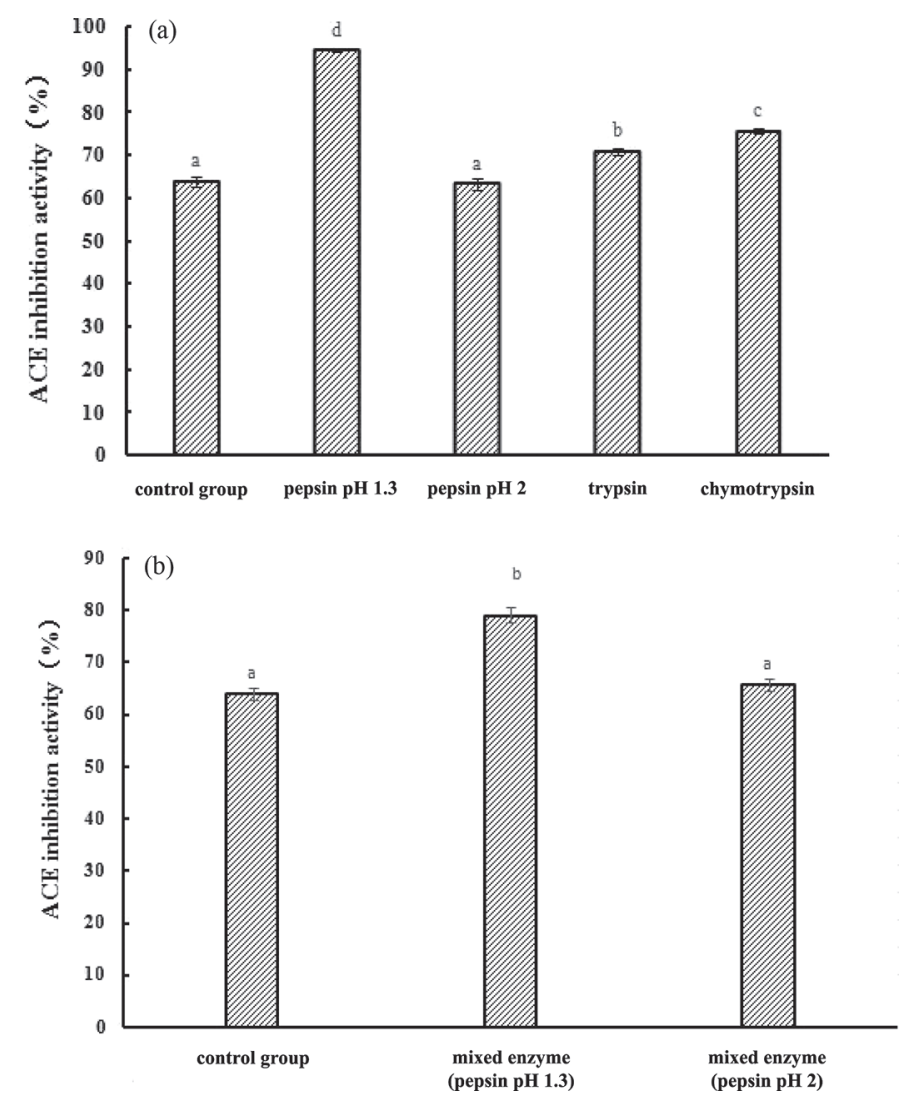

Figure 6. Angiotensin-converting enzyme (ACE) inhibition activity after treatment by gastrointestinal enzymes. (a) Single enzyme treatment; means with different letters (a-d) are significantly different $(P<0.05)$. (b) Mixed enzyme treatment; means with different letters (a,b) are significantly different $(P<0.05)$. Error bars represent SE. 


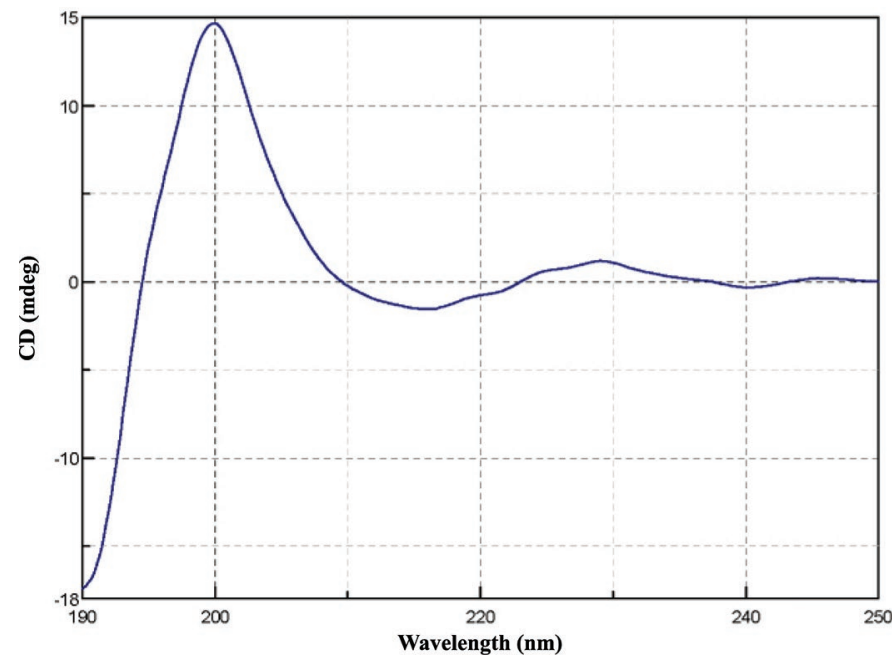

Figure 7. Circular dichroism (CD) spectrum of LPYPY (Leu-ProTyr-Pro-Tyr).

secondary structure consisting mainly of a $\beta$-sheet. The results of the present study suggested additional opportunities for the use of whey proteins, including the exploitation of the byproduct of milk fermented by $L$. delbrueckii QS306, as source of natural ACE inhibitory peptides. Further studies will be performed to confirm the AA sequence of component D using HPLC, and to determine the sequence of the other peaks with high ACEI activity in component C. We will use molecular docking simulations to confirm quantitative effective mechanism of the high ACEI activity peptides and to determine the effects of peptides on inhibiting high blood pressure in vivo. Moreover, we will use a microcapsule delivery method to protect the ACEI activity and DPP-IV inhibition activity of LPYPY.

\section{ACKNOWLEDGMENTS}

This work was supported by the National Science Foundation of China (grant no. 31460443) and the Municipality Technology Support Project of Inner Mongolia (grant no. KCBJ2018011).

\section{REFERENCES}

Antman, E. M., L. J. Appel, D. Balentine, R. K. Johnson, L. M. Steffen, E. A. Miller, A. Pappas, K. F. Stitzel, D. K. Vafiadis, and L. Whitsel. 2014. Stakeholder discussion to reduce population-wide sodium intake and decrease sodium in the food supply: A conference report from the American Heart Association Sodium Conference 2013 Planning Group. Circulation 129:e660-e679. https://doi .org/10.1161/CIR.0000000000000051.

Archer, A. C., N. K. Kurrey, and P. M. Halami. 2018. In vitro adhesion and anti-inflammatory properties of native Lactobacillus fermentum and Lactobacillus delbrueckii spp. J. Appl. Microbiol. 125:243-256. https://doi.org/10.1111/jam.13757.
Bernstein, K. E., F. S. Ong, W. L. Blackwell, K. H. Shah, J. F. Giani, R. A. Gonzalez-Villalobos, X. Z. Shen, S. Fuchs, and R. M. Touyz. 2012. A modern understanding of the traditional and nontraditional biological functions of angiotensin-converting enzyme. Pharmacol. Rev. 65:1-46. https://doi.org/10.1124/pr.112.006809.

Chen, J., Y. Wang, Q. Zhong, Y. Wu, and W. Xia. 2012. Purification and characterization of a novel angiotensin-I converting enzyme (ACE) inhibitory peptide derived from enzymatic hydrolysate of grass carp protein. Peptides 33:52-58. https://doi.org/10.1016/j .peptides.2011.11.006.

Cho, W. M., B. P. Joshi, H. Cho, and K. H. Lee. 2007. Design and synthesis of novel antibacterial peptide-resin conjugates. Bioorg. Med. Chem. Lett. 17:5772-5776. https://doi.org/10.1016/j.bmcl 2007.08.056.

Cushman, D. W., and H. S. Cheung. 1971. Spectrophotometric assay and properties of the angiotensin-converting enzyme of rabbit lung. Biochem. Pharmacol. 20:1637-1648. https://doi.org/10 .1016/0006-2952(71)90292-9.

Daliri, B. M., B. H. Lee, J. H. Kim, and D. H. Oh. 2018. Novel angiotensin I-converting enzyme inhibitory peptides from soybean protein isolates fermented by Pediococcus pentosaceus SDL1409. Lebensm. Wiss. Technol. 93:88-93. https://doi.org/10.1016/j.lwt .2018.03.026.

Ehlers, M. R., and J. F. Riordan. 1989. Angiotensin-converting enzyme: New concepts concerning its biological role. Biochemistry 28:5311-5318. https://doi.org/10.1021/bi00439a001.

Fang, X. P., W. S. Xia, Q. H. Sheng, and Y. L. Wang. 2007. Purification and characterization of an immunomodulatory peptide from bovine placenta water-soluble extract. Prep. Biochem. Biotechnol. 37:173-184. https://doi.org/10.1080/10826060701386653.

Gómez-Ruiz,. J. A., M. Ramos, and I. Recio. 2007. Identification of novel angiotensin-converting enzyme-inhibitory peptides from ovine milk proteins by CE-MS and chromatographic techniques. Electrophoresis 28:4202-4211. https://doi.org/10.1002/elps .200700324 .

Gonzalez-Gonzalez, C., T. Gibson, and P. Jauregi. 2013. Novel probiotic-fermented milk with angiotensin I-converting enzyme inhibitory peptides produced by Bifidobacterium bifidum MF 20/5. Int. J. Food Microbiol. 167:131-137. https://doi.org/10.1016/j .ijfoodmicro.2013.09.002.

Guerrero, L., J. Castillo, M. Quiñones, S. Garcia-Vallvé, L. Arola, G. Pujadas, and B. Muguerza. 2012. Inhibition of angiotensin-converting enzyme activity by flavonoids: Structure-activity relationship studies. PLoS One 7:e49493. https://doi.org/10.1371/journal .pone.0049493.

Hernandez-Ledesma, B., B. Miralles, L. Amigo, M. Ramos, and I. Recio. 2010. Identification of antioxidant and ACE-inhibitory peptides in fermented milk. J. Sci. Food Agric. 85:1041-1048. https:/ /doi.org/10.1002/jsfa.2063.

Jang, A., and M. Lee. 2005. Purification and identification of angiotensin converting enzyme inhibitory peptides from beef hydrolysates. Meat Sci. 69:653-661. https://doi.org/10.1016/j.meatsci.2004.10 .014 .

Jia, J. Q., H. L. Ma, W. R. Zhao, Z. B. Wang. W. M. Tian, L. Lin, and R. H. He. 2010. The use of ultrasound for enzymatic preparation of ACE-inhibitory peptides from wheat germ protein. Food Chem. 119:336-342. https://doi.org/10.1016/j.foodchem.2009.06.036.

Jimsheena, V. K., and R. G. Lalitha. 2010. Arachin derived peptides as selective angiotensin I-converting enzyme (ACE) inhibitors: Structure-activity relationship. Peptides 31:1165-1176. https:// doi.org/10.1016/j.peptides.2010.02.022.

Kumar, N., and C. Yin. 2018. The anti-inflammatory peptide Ac-SDKP: Synthesis, role in ACE inhibition, and its therapeutic potential in hypertension and cardiovascular diseases. Pharmacol. Res. 134:268-279. https://doi.org/10.1016/j.phrs.2018.07.006.

Kumar, S., D. R. Maury, and M. Chandra. 2000. ACE inhibition versus angiotensin-II antagonism in heart failure. Asian Cardiovasc. Thorac. Ann. 8:195-203. https://doi.org/10.1177/ 021849230000800229.

Li, B., D. Jin, S. Yu, E. S. Etareri, Z. Muhammad, G. Huo, and F. Liu. 2017. In vitro and in vivo evaluation of Lactobacillus delbrueckii 
ssp. bulgaricus KLDS1.0207 for the alleviative effect on lead toxicity. Nutrients 9:E845. https://doi.org/10.3390/nu9080845.

Liu, J. B., Z. P. Yu, W. Z. Zhao, S. Y. Lin, E. L. Wang, Z. Yan, H. Hui, Z. Z. Wang, and F. Chen. 2010. Isolation and identification of angiotensin-converting enzyme inhibitory peptides from egg white protein hydrolysates. Food Chem. 122:1159-1163. https://doi.org/ 10.1016/j.foodchem.2010.03.108.

Makino, S., J. Hemmi, H. Kano, M. Kashiwagi, K. Hojo, and Y. Asami. 2018. Anti-fatigue effects of yogurt fermented with Lactobacillus delbrueckii ssp. bulgaricus OLL1073R-1 in healthy people suffering from summer heat fatigue: A randomized, double-blind, placebo-controlled trial. Nutrients 10:E798. https://doi.org/10 $.3390 /$ nu10070798.

Minervini, F., F. Algaron, C. G. Rizzello, P. F. Fox, V. Monnet, and M. Gobbetti. 2003. Angiotensin I-converting-enzyme-inhibitory and antibacterial peptides from Lactobacillus helveticus PR4 proteinase-hydrolyzed caseins of milk from six species. Appl. Environ. Microbiol. 69:5297-5305. https://doi.org/10.1128/AEM.69.9.5297 -5305.2003 .

Moreno-Montoro, M., P. Jauregi, M. Navarro-Alarcón, M. Olalla-Herrera, R. Giménez-Martínez, L. Amigo, and B. Miralles. 2018. Bioaccessible peptides released by in vitro gastrointestinal digestion of fermented goat milks. Anal. Bioanal. Chem. 410:3597-3606. https: //doi.org/10.1007/s00216-018-0983-0.

Nagata, S., K. Takeyama, K. Hosoki, and T. Karasawa. 1997. Possible involvement of ATP-dependent K-channel related mechanisms in the antihypertensive and cough suppressant effects of the novel ACE inhibitor (2S, 3aS, 7aS)-1-(N2-nicotinoyl-L-lysyl-gammaD-glutamyl)octahydro-1H-indole-2-carboxylic acid. Arzneimittelforschung 47:726-730.

Nakamura, Y., N. Yamamoto, K. Sakai, A. Okubo, S. Yamazaki, and T. Takano. 1995a. Purification and characterization of angiotensin I-converting enzyme inhibitors from sour milk. J. Dairy Sci. 78:777-783. https://doi.org/10.3168/jds.S0022-0302(95)76689-9.

Nakamura, Y., N. Yamamoto, K. Sakai, and T. Takano. 1995b. Antihypertensive effect of sour milk and peptides isolated from it that are inhibitors to angiotensin I-converting enzyme. J. Dairy Sci. 78:1253-1257. https://doi.org/10.3168/jds.S0022-0302(95)76745 -5 .

Ngo, D. H., B. Ryu, and S. K. Kim. 2014. Active peptides from skate (Okamejei kenojei) skin gelatin diminish angiotensin-I converting enzyme activity and intracellular free radical-mediated oxidation. Food Chem. 143:246-255. https://doi.org/10.1016/j.foodchem 2013.07.067.

Nolan, R. P., R. Feldman, M. Dawes, J. Kaczorowski, H. Lynn, S. I. Barr, C. MacPhail, S. Thomas, J. Goodman, G. Eysenbach, S. Liu, R. Tanaka, and J. Surikova. 2018. Randomized controlled trial of E-counseling for hypertension: REACH. Circ. Cardiovasc. Qual. Outcomes 11:e004420. https://doi.org/10.1161/ CIRCOUTCOMES.117.004420.

Nongonierma, A. B., and R. J. Fitzgerald. 2014. Susceptibility of milk protein-derived peptides to dipeptidyl peptidase IV (DPP-IV) hydrolysis. Food Chem. 145:845-852. https://doi.org/10.1016/j .foodchem.2013.08.097.

Norris, R., M. B. O'Keeffe, A. Poyarkov, and R. J. Fitzgerald. 2015. Peptide identification and angiotensin converting enzyme (ACE) inhibitory activity in prolyl endoproteinase digests of bovine Qs-casein. Food Chem. 188:210-217. https://doi.org/10.1016/j .foodchem.2015.04.130.

Radó, J. P., M. Csabuda, and C. Bános. 1985. Influence of body posture on aldosterone suppression after antihypertensive drugs (captopril and metoprolol). Horm. Metab. Res. 17:615-616. https://doi .org/10.1055/s-2007-1013622.

Seppo, L., T. Jauhiainen, T. Poussa, and R. Korpela. 2003. A fermented milk high in bioactive peptides has a blood pressure-lowering effect in hypertensive subjects. Am. J. Clin. Nutr. 77:326-330. https://doi.org/10.1093/ajcn/77.2.326.

Shori, A. B., and A. S. Baba. 2014. Comparative antioxidant activity, proteolysis and in vitro $\alpha$-amylase and $\alpha$-glucosidase inhibition of Allium sativum-yogurts made from cow and camel milk. J. Saudi Chem. Soc. 18:456-463. https://doi.org/10.1016/j.jscs.2011 .09.014.

Solieri, L., R. Giuseppina Sefora, and D. Tagliazucchi. 2015. Impact of non-starter lactobacilli on release of peptides with angiotensinconverting enzyme inhibitory and antioxidant activities during bovine milk fermentation. Food Microbiol. 51:108-116. https://doi .org/10.1016/j.fm.2015.05.012.

Tikhomirova, V. E., O. A. Kost, O. V. Kryukova, E. Z. Golukhova, N. I. Bulaeva, A. Z. Zholbaeva, L. A. Bokeria, J. G. N. Garcia, and S. M. Danilov. 2017. ACE phenotyping in human heart. PLoS One 12:e0181976. https://doi.org/10.1371/journal.pone.0181976.

Tsai, J. S., Y. S. L. S. Pan, and T. J. Chen. 2006. Antihypertensive peptides and $\gamma$-aminobutyric acid from prozyme 6 facilitated lactic acid bacteria fermentation of soymilk. Process Biochem. 41:12821288. https://doi.org/10.1016/j.procbio.2005.12.026.

Tu, M., C. Wang, C. Chen, R. Zhang, H. Liu, W. Lu, L. Jiang, and M. Du. 2018. Identification of a novel ACE-inhibitory peptide from casein and evaluation of the inhibitory mechanisms. Food Chem. 256:98-104. https://doi.org/10.1016/j.foodchem.2018.02.107.

Usui, Y., Y. Kimura, and T. Satoh. 2018. Effects of long-term intake of a yogurt fermented with Lactobacillus delbrueckii ssp. bulgaricus 2038 and Streptococcus thermophilus 1131 on mice. Int. Immunol. 30:319-331. https://doi.org/10.1093/intimm/dxy035.

WHO (World Health Organization). 2016. WHO | Cardiovascular diseases (CVDs) Fact sheet N 317. 10-20-2018. http://www.who.int/ en/news-room/fact-sheets/detail/cardiovascular-diseases-(cvds).

Wu, J., R. E. Aluko, and S. Nakai. 2006. Structural requirements of Angiotensin I-converting enzyme inhibitory peptides: Quantitative structure-activity relationship study of di- and tripeptides. J. Agric. Food Chem. 54:732-738. https://doi.org/10.1021/jf0512631.

Zafari, N., S. Asgari, M. Lotfaliany, A. Hadaegh, F. Azizi, and F. Hadaegh. 2017. Impact of hypertension versus diabetes on cardiovascular and all-cause mortality in Iranian older adults: Results of 14 years of follow-up. Sci. Rep. 7:14220. https://doi.org/10.1038/ s41598-017-14631-2.

Zhang, T., S. Nie, B. Liu, Y. Yu, Y. Zhang, and J. Liu. 2015. Activity prediction and molecular mechanism of bovine blood derived angiotensin I-converting enzyme inhibitory peptides. PLoS One 10:e0119598. https://doi.org/10.1371/journal.pone.0119598. 